\title{
Article \\ Direct Seeding and Transplanting Influence Root Dynamics, Morpho-Physiology, Yield, and Head Quality of Globe Artichoke
}

\author{
Daniel I. Leskovar ${ }^{1, *(\mathbb{D})}$ and Yahia A. Othman ${ }^{1,2} \mathbb{D}$ \\ 1 Texas A\&M AgriLife Research and Extension Center, Texas A\&M University, Uvalde, TX 78801, USA; \\ ya.othman@ju.edu.jo \\ 2 Department of Horticulture and Crop Science, The University of Jordan, Amman 11942, Jordan \\ * Correspondence: d-leskovar@tamu.edu
}

Citation: Leskovar, D.I.; Othman,

Y.A. Direct Seeding and

Transplanting Influence Root

Dynamics, Morpho-Physiology, Yield, and Head Quality of Globe Artichoke. Plants 2021, 10, 899. https://doi.org/ 10.3390/plants10050899

Academic Editor: Mariana Amato

Received: 27 March 2021

Accepted: 26 April 2021

Published: 29 April 2021

Publisher's Note: MDPI stays neutral with regard to jurisdictional claims in published maps and institutional affiliations.

Copyright: (C) 2021 by the authors. Licensee MDPI, Basel, Switzerland. This article is an open access article distributed under the terms and conditions of the Creative Commons Attribution (CC BY) license (https:// creativecommons.org/licenses/by/ $4.0 /)$.

\begin{abstract}
The objective of this two-year field study was to assess the influence of stand establishment methods (direct seeding or transplanting) on root growth dynamics, shoot morphology, leaf physiology, yield, and quality of globe artichoke (Cynara cardunculus). Three artichoke cultivars were evaluated, 'Green Globe Improved' (GGI), 'Imperial Star' (IS), and 'Romolo' (ROM). Plants established with the transplanting method had higher mean root length intensity (La), root length, and root surface area as compared to plants established by direct seeding. The topsoil $(0-20 \mathrm{~cm})$ had on average higher La, root length, and root surface area than deeper soil profiles. Transplanted plants had higher plant shoot width and leaf area index (LAI) chlorophyll content index (SPAD) than direct seeded plants at the vegetative stage in 2015. The improvement of root and shoot growth in transplants (compared to direct seeding) also resulted in higher $(p<0.05)$ marketable yield (21.1 vs. 19.9 ton $\mathrm{ha}^{-1}$ in 2015 and 18.3 vs. 13.7 ton $\mathrm{ha}^{-1}$ in 2016). Additionally, 46-50\% of the total yield occurred during the first 30 days of harvest in the transplanting method compared to $13-38 \%$ for direct seeding. No significant differences were found between planting methods or cultivars in leaf-level gas exchange (photosynthesis, stomatal conductance, and transpiration) and cynarin concentration in the marketable heads. Although chlorogenic acid was similar in both establishment methods in 2015, direct seeding had higher concentration in 2016. Comparing cultivars, GGI had higher root length, surface area, root volume, and earlier and higher marketable yield than ROM. However, ROM had higher mean root length intensity ( $L a$; total root length per specific area in soil profile) than GGI in both growing seasons. This study showed significant and consistent improvements in root and shoot traits, and yield for transplants as compared to direct seeded plants.
\end{abstract}

Keywords: Cynara cardunculus; root length; minirhizotron; yield; SPAD; chlorogenic acid

\section{Introduction}

Farming systems, nitrogen management, cultivar selection, and planting methods such as direct seeding and transplanting are cultural strategies that greatly influence root and shoot growth, yield, and fruit quality in high-value vegetable crops [1-4]. In bell pepper (Capsicum annuum), earlier studies comparing direct seeding with containerized transplants produced in nurseries showed significant effects on growth (leaf area and shoot weight) and developmental stages in the field [5]. For certain crop species (e.g., onion, rice) established at high planting density, direct seeding has been considered a cost-effective method of stand establishment since transplanting would require the additional costs for raising the transplants in nurseries and high labor costs of transplanting [6,7]. However, consideration of the high seed cost and lower seedling survival in direct seeding is important, especially for high-value vegetable crops that are typically hybrids instead of open pollinated cultivars. The applicability and success of direct seeding depends on seed quality, knowledge of appropriate sowing times and rates, seedbed preparation, field germination, emergence, 
and resource competition from emerging weeds [8]. The main constraints on stand success from direct seeding that could lead to high mortality are poor germination, uneven stands, transient or persistent environmental stresses (episodes of droughts, desiccation events, floods, excessive heat), diseases, weed competition, and limited nutrients [7]. Artichoke (Cynara cardunculus) fields established with the transplanting method typically have less weed pressure and disease problems and higher yield and head uniformity as compared to direct seeding [9]. Transplant quality can also be improved during the nursery stage by optimizing the nitrogen nutrition of the growing substrate in the tray cells, a practice that was shown to mitigate the transplanting shock during stand establishment of globe artichoke [3].

Transplanting is a reliable method to improve growth and achieve earliness and higher yield, as reported for several crops, including onion (Allium cepa), rice (Oryza sativa), bell pepper, tomato (Solanum lycopersicum), and watermelon (Citrullus lanatus) $[1,5,6,10]$. Onion established by transplanting resulted in higher yield $\left(36.3 \mathrm{t} \mathrm{ha}^{-1}\right)$ than direct seeding (19.5 $\mathrm{t} \mathrm{ha}^{-1}$ ) and matured earlier (104 days) compared to the direct seeded (135 days) method [6]. However, the transplanting date for onion (early, mid-, or late planting) is critical to produce higher yield [11]. Transplanted rice had higher leaf chlorophyll content index (SPAD), N concentration, total root length, and total root tip number than direct seeded plants [12]. In southern England, a suitable combination of cultivar and age of transplants shortened the growth period and enabled corn plants to meet the thermal time requirement for a grain harvest [1]. In tomato, transplants had earlier and higher yield than direct seeded plant [5]. In smallholder farms in South Africa, the adoption of mature transplants over direct seeding to establish corn plants has significantly increased survival and decreased the damage caused by birds during early developmental stages [2]. A comparative review of using direct seeding and seedling plantings in restoration projects revealed that the successful survival percentage of transplants was three times higher than direct seeding, especially when using larger seeds (Albizia, Acacia, Phyllanthus, and Ocotea) [7].

Root traits such as root length, root surface area, and length intensity ( $\mathrm{La}$; total root length per specific area in the soil profile) can significantly affect plant morphology and leaf physiology, as reported in globe artichoke and olive crops $[3,4,13]$. Planting methods can also affect early root development, root and shoot biomass allometric partitioning, fruit development, and marketable yields [2,14,15]. For example, in bell pepper, transplanted plants had higher basal root dry weight percentage (transplants, $81 \%$ vs. direct seeded plants, $25 \%$ ) and smaller lateral roots (15\% vs. $57 \%$ ) and taproot ( $4 \%$ vs. $18 \%)$. While direct seeded plants sustained more balanced root, stem, leaf, and fruit dry matter partitioning than transplants, the latter exhibited higher and earlier yields [15].

Plant internal factors, such as leaf anatomy and morpho-physiology, can significantly affect growth and development, as well as yield [16]. Photosynthesis (Pn) normally increases rapidly from leaf emergence, reaching maximum values at full leaf expansion. Physiological performance, including $P n$ and stomatal conductance $(g \mathrm{~s})$, can increase due to higher leaf thickness and contents of chlorophyll $(a+b)$ and palisade parenchyma because those leaf variables help to capture a greater amount of light $[16,17]$. However, the effects of those internal factors in artichoke have not been well studied in direct seeded and transplanted plants.

Globe artichoke is a popular Mediterranean crop rich in antioxidant compounds such as chlorogenic acid, dicaffeoylquinic acids, and cynarin, which are known to be beneficial for human health $[18,19]$. In addition to genotype, cultural practices and farming systems have been shown to affect the content of chlorogenic acid, with ranges from 60-600 $\left(\mu \mathrm{g} \mathrm{g}^{-1}\right)$, and cynarin from 2 to $20\left(\mu \mathrm{g} \mathrm{g}^{-1}\right)$ [20-23]. In organic farming, head chlorogenic acid increased by $31 \%$ and cynarin by $12 \%$ compared to those grown in conventional fields [19]. Shinohara et al. [24] also found that irrigation practices were more effective than the selection of $\mathrm{N}$ rates to optimize artichoke crop yield and head quality (chlorogenic acid). To date, the impact of planting method in root growth dynamics and 
head quality of artichoke cultivars has not been investigated. Accordingly, the objective of this study was to determine the differential expression of shoot and root traits (root length, surface area, volume, diameter, and $\mathrm{La}$ ) in relation to the most common planting methods (transplant vs. direct seeding). We hypothesize that when compared to direct seeded plants, artichoke transplants will have a differential root growth pattern, with more biomass allocation directed towards root length, especially during the vegetative developmental stage and for early cultivars; these responses will in turn translate into improvements in early and total marketable yield. The findings of this study contribute to new knowledge centered on the importance of root traits to improve crop growth and productivity of artichoke transplants.

\section{Results}

Table 1 shows the ANOVA and mean separation (LSD) for La as affected by planting method, cultivar, and soil depth for two growing seasons, 2015-2016. Plants analyzed in 2015 were transplanted (or sown) in October 2014 while the 2016 plants were transplanted (or sown) in November 2015. Since the study considered the annual system the 2015-started plants were terminated at the end of the cycle and thus not analyzed in 2016. Mean La was significantly different for planting method, cultivar, and soil depth during 2015 and 2016. Transplants had higher mean La in both years (2015-2016) as well as the overall means. Root length values for direct seeded plants never exceeded those of transplants across months and over the study period 2015-2016. However, La response varied with cultivars. For example, ROM and IS had higher root La in March and April 2015 while GGI had higher La than IS in July 2015 and 2016 (Table 1). The main La values (>90\%) for the three tested artichoke cultivars were within $0-80 \mathrm{~cm}$ of soil depth. A soil depth of $0-20 \mathrm{~cm}$ had the highest mean La in 2015 while the 20-40 and 40-60 La were higher than the other soil depths in 2016. However, the overall mean (2015-2016) for La was similar across the $0-60 \mathrm{~cm}$ soil depths.

Table 1. Mean root length intensity $\left(\mathrm{La}, \mathrm{mm} \mathrm{cm}^{-2}\right.$ ) of artichoke cultivars (Green Globe Improved (GGI), Romolo (ROM), and Imperial Star (IS)) as influenced by planting method (direct seeding —Seed, and transplanting - transplant) and soil depth during 2015 and 2016 seasons. Data were collected using the minirhizotron root system.

\begin{tabular}{|c|c|c|c|c|c|c|c|c|c|c|c|}
\hline \multirow{3}{*}{ Main Effect } & \multicolumn{11}{|c|}{ Root Length Intensity $\left(\mathrm{La}, \mathrm{mm} \mathrm{cm}^{-2}\right)$} \\
\hline & \multicolumn{5}{|c|}{2015} & \multicolumn{5}{|c|}{2016} & \multirow{2}{*}{$\begin{array}{c}\text { Overall } \\
\text { Mean }\end{array}$} \\
\hline & March & April & May & July & Mean & March & May & June & July & Mean & \\
\hline \multicolumn{12}{|l|}{$\begin{array}{l}\text { Planting } \\
\text { method (P) }\end{array}$} \\
\hline Seed & $0.72 \mathrm{a}$ & $1.46 \mathrm{~b}$ & $1.03 \mathrm{a}$ & $0.81 \mathrm{a}$ & $1.01 \mathrm{~b}$ & $0.29 \mathrm{a}$ & $1.27 \mathrm{a}$ & $0.48 \mathrm{a}$ & $1.97 \mathrm{~b}$ & $1.01 \mathrm{~b}$ & $1.01 \mathrm{~b}$ \\
\hline $\begin{array}{l}\text { Transplant } \\
\text { Cultivar (C) }\end{array}$ & $0.87 \mathrm{a}$ & $2.54 \mathrm{a}$ & $1.22 \mathrm{a}$ & $1.12 \mathrm{a}$ & $1.43 \mathrm{a}$ & $0.49 \mathrm{a}$ & $1.32 \mathrm{a}$ & $0.55 \mathrm{a}$ & $7.22 \mathrm{a}$ & $2.40 \mathrm{a}$ & $1.92 \mathrm{a}$ \\
\hline GGI & $0.53 \mathrm{~b}$ & $1.01 \mathrm{~b}$ & $1.40 \mathrm{a}$ & $1.26 \mathrm{a}$ & $1.07 \mathrm{~b}$ & $0.21 \mathrm{~b}$ & $1.91 \mathrm{a}$ & $0.08 \mathrm{c}$ & $8.06 \mathrm{a}$ & $2.56 \mathrm{a}$ & $1.82 \mathrm{a}$ \\
\hline ROM & $0.71 \mathrm{a}$ & $2.63 \mathrm{a}$ & $1.39 \mathrm{a}$ & $1.04 \mathrm{ab}$ & $1.51 \mathrm{a}$ & $0.92 \mathrm{a}$ & $1.01 \mathrm{~b}$ & $0.42 \mathrm{~b}$ & $3.43 \mathrm{~b}$ & $1.44 \mathrm{~b}$ & $1.48 \mathrm{~b}$ \\
\hline IS & $0.56 \mathrm{a}$ & $2.27 \mathrm{a}$ & $0.60 \mathrm{~b}$ & $0.59 \mathrm{~b}$ & $1.08 \mathrm{~b}$ & $0.06 \mathrm{c}$ & $0.95 \mathrm{~b}$ & $1.05 \mathrm{a}$ & $2.31 \mathrm{c}$ & $1.09 \mathrm{~b}$ & $1.01 \mathrm{c}$ \\
\hline \multicolumn{12}{|l|}{ Depth (D, cm) } \\
\hline 20 & $1.06 \mathrm{a}$ & $2.52 \mathrm{a}$ & $1.77 \mathrm{a}$ & $1.86 \mathrm{a}$ & $1.80 \mathrm{a}$ & $1.06 \mathrm{a}$ & $1.43 \mathrm{ab}$ & $0.66 \mathrm{a}$ & $3.91 \mathrm{~cd}$ & $1.77 \mathrm{~b}$ & $1.78 \mathrm{a}$ \\
\hline 40 & $1.05 \mathrm{a}$ & $1.95 \mathrm{ab}$ & $0.78 \mathrm{~b}$ & $0.93 \mathrm{~b}$ & $1.18 \mathrm{~b}$ & $0.39 \mathrm{~b}$ & $1.92 \mathrm{a}$ & $0.69 \mathrm{a}$ & $6.34 \mathrm{a}$ & $2.33 \mathrm{a}$ & $1.76 \mathrm{a}$ \\
\hline 60 & $1.01 \mathrm{a}$ & $2.17 \mathrm{a}$ & $1.08 \mathrm{~b}$ & $0.90 \mathrm{~b}$ & $1.29 \mathrm{~b}$ & $0.33 \mathrm{bc}$ & $1.50 \mathrm{ab}$ & $0.51 \mathrm{a}$ & $5.66 \mathrm{ab}$ & $2.00 \mathrm{ab}$ & $1.65 \mathrm{a}$ \\
\hline 80 & $0.68 \mathrm{a}$ & $1.95 \mathrm{ab}$ & $1.14 \mathrm{~b}$ & $0.69 \mathrm{~b}$ & $1.12 \mathrm{~b}$ & $0.14 \mathrm{bc}$ & $1.17 \mathrm{~b}$ & $0.43 a$ & $4.51 \mathrm{bc}$ & $1.56 \mathrm{~b}$ & $1.34 \mathrm{~b}$ \\
\hline \multirow{2}{*}{\multicolumn{12}{|c|}{ ANOVA }} \\
\hline & & & & & & & & & & & \\
\hline $\mathrm{P}$ & NS & $* * *$ & NS & NS & $* * *$ & + & NS & NS & $* * *$ & $* * *$ & $* * *$ \\
\hline C & $* *$ & $* * *$ & $* *$ & $*$ & $* *$ & $* * *$ & $* *$ & $* * *$ & $* * *$ & $* * *$ & $* * *$ \\
\hline $\mathrm{P} \times \mathrm{C}$ & $* *$ & $* * *$ & NS & ** & $* * *$ & $* * *$ & $*$ & $* *$ & $* * *$ & $* *$ & NS \\
\hline $\mathrm{D}$ & $* * *$ & $* *$ & $* *$ & $* *$ & $* * *$ & $* * *$ & $*$ & NS & $* * *$ & $* *$ & $* * *$ \\
\hline$P \times D$ & NS & NS & NS & NS & NS & $* * *$ & NS & NS & NS & NS & NS \\
\hline $\mathrm{C} \times \mathrm{D}$ & $* *$ & $* * *$ & $* * *$ & NS & $* * *$ & $* * *$ & NS & NS & $*$ & $t$ & $* *$ \\
\hline $\mathrm{P} \times \mathrm{C} \times \mathrm{D}$ & NS & NS & NS & $*$ & $*$ & $* * *$ & NS & NS & NS & NS & $* *$ \\
\hline
\end{tabular}

$\dagger^{*}{ }^{* * *}, * * *$ show significant differences at $p<0.1,0.05,0.01$, and 0.001 , respectively. NS, not significant at $p<0.1$. Means in columns followed by different letters are significantly different at $p<0.05$. 
There was a significant planting method and cultivar interaction for La across months and over the study period 2015-2016, except in May 2015 (Table 1 and Figure 1). The planting method and cultivar interactions revealed that, in both years, La values from the transplanting method were higher or similar (never lower) to direct seeding across the soil depths (0-100) and cultivars (GGI, ROM, IS), except for GGI at a 0-20 cm soil depth in 2015 (Figure 1).

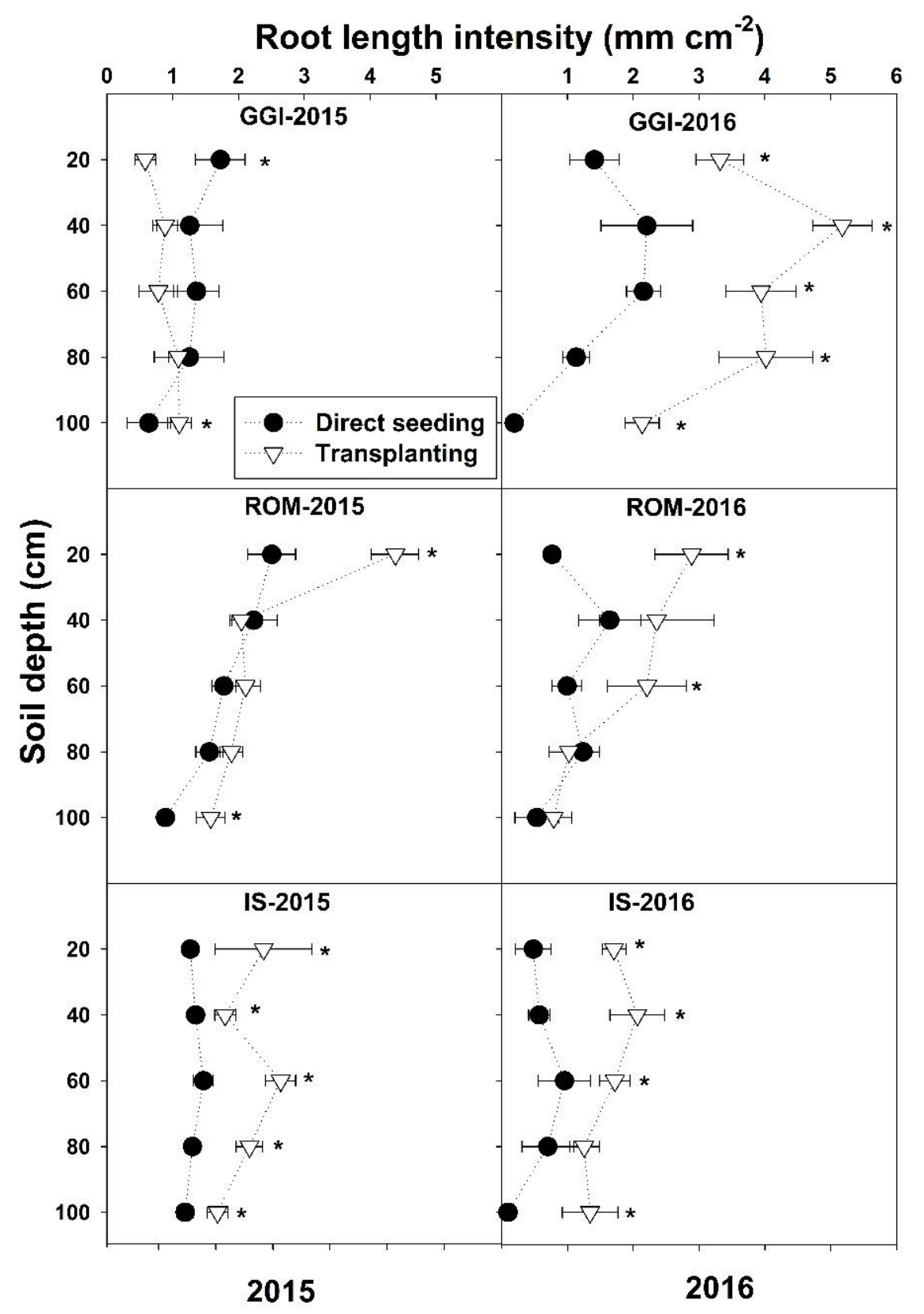

Figure 1. Mean root length intensity at different soil depths for artichoke cultivars (Green Globe Improved (GGI), Romolo (ROM) and Imperial Star (IS)) as influenced by establishment method (direct seeding and transplanting) during 2015 and 2016 seasons. Data were collected using minirhizotron root system. Asterisk $\left({ }^{*}\right)$ within each soil depth represents significant differences between treatments at $p<0.05$.

In both years (2015-2016), artichoke plants had the lowest La (0-100 cm soil depth) during the vegetative stages (March, about four months after planting) across planting methods (direct seeding and transplanting) and over cultivars (GGI, IS, ROM) (Figure 2). 
Both direct seeding and transplanting La values were low in March, peaked during the harvesting period (April), and decreased thereafter (July) in 2015. However, both planting methods had the highest La after harvest (July) in 2016 (Figure 2). Roots in 2016 were longer (about 40\%)than those in 2015. Similar trends were noticed for tested cultivars in both years, except for GGI in 2015.
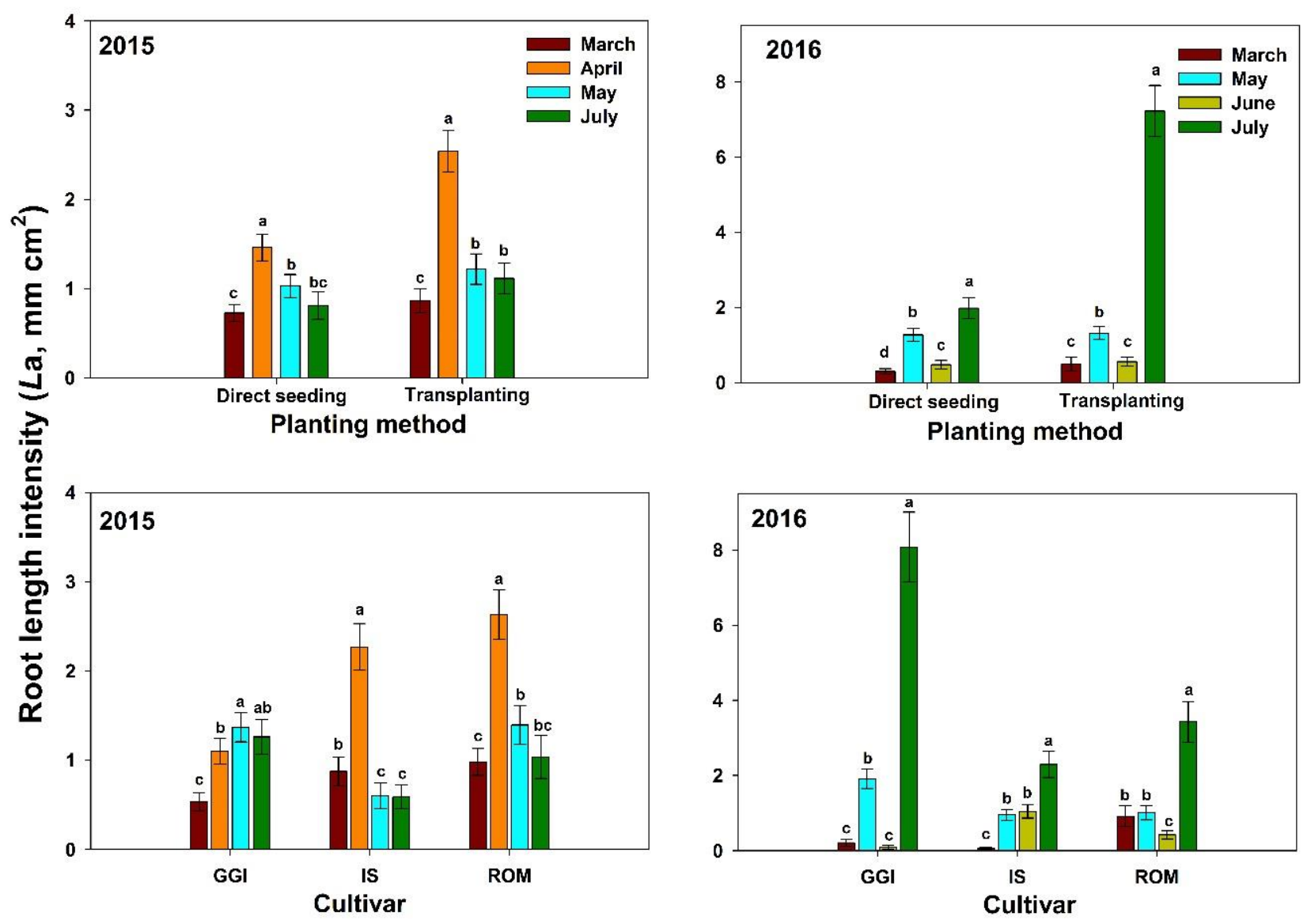

Figure 2. Mean root length intensity at soil depth 0-100 cm for artichoke cultivars (Green Globe Improved (GGI), Romolo (ROM) and Imperial Star (IS)) as influenced by planting method (direct seeding and transplanting) during 2015 and 2016 seasons. Data were collected using the minirhizotron root system. Bars within the same harvesting date followed by different letters are significantly different at $p<0.05$.

Soil cores sampling in July 2015 revealed that root component values, specifically length and surface area from the transplanting method, were higher than those from direct seeding (Table 2). The GGI cultivar had consistently higher root length, surface area, and volume than ROM. While the artichoke plants from a $0-20 \mathrm{~cm}$ soil depth had higher root length and surface area than the $20-40$ or $40-60 \mathrm{~cm}$ depths, root volumes from these combined lower depths $(20-60 \mathrm{~cm})$ were higher than at the topsoil layer, 0-20 $\mathrm{cm}$ (Table 2). Planting method $\times$ cultivar showed that transplanting resulted in longer or similar (never shorter) root length than direct seeding across soil depths $(0-60 \mathrm{~cm})$ and cultivars (GGI, ROM, IS) (Figure 2). Similarly, root surface area in transplanted artichokes was larger than in direct seeded plants, except for GGI at a soil depth of $20-40 \mathrm{~cm}$. For root diameter and volume, the planting method $\times$ cultivar interactions were inconsistent or not significant across soil depths. For example, at $20-40 \mathrm{~cm}$, GGI cultivar root volume from the direct seeding treatment was larger than for transplants, while IS from direct seeding had lower values at the same soil depth (Figure 3). 
Table 2. Root trait components of artichoke cultivars (Green Globe Improved (GGI), Romolo (ROM), and Imperial Star (IS)) as influenced by planting method (direct seeding-Seed, and transplanting-Transplant) and soil depth during the harvesting period, July 2015.

\begin{tabular}{|c|c|c|c|c|}
\hline Main Effect & Length $(\mathrm{cm})$ & Surface Area $\left(\mathrm{cm}^{2}\right)$ & Average Diameter (mm) & Volume $\left(\mathrm{cm}^{3}\right)$ \\
\hline \multicolumn{5}{|c|}{ Planting method (P) } \\
\hline Seed & $136 \mathrm{~b}$ & $10.6 \mathrm{~b}$ & $0.32 \mathrm{a}$ & $0.10 \mathrm{a}$ \\
\hline Transplant & $231 \mathrm{a}$ & $15.2 \mathrm{a}$ & $0.29 \mathrm{a}$ & $0.09 \mathrm{a}$ \\
\hline \multicolumn{5}{|l|}{ Cultivar (C) } \\
\hline GGI & $197 \mathrm{a}$ & $15.5 \mathrm{a}$ & $0.35 \mathrm{a}$ & $0.14 \mathrm{a}$ \\
\hline ROM & $119 \mathrm{~b}$ & $10.6 \mathrm{~b}$ & $0.34 \mathrm{a}$ & $0.09 \mathrm{~b}$ \\
\hline IS & $235 \mathrm{a}$ & $12.6 \mathrm{~b}$ & $0.22 \mathrm{~b}$ & $0.06 \mathrm{~b}$ \\
\hline \multicolumn{5}{|l|}{ Depth (D) } \\
\hline 20 & $330 \mathrm{a}$ & $20.0 \mathrm{a}$ & $0.22 \mathrm{~b}$ & $0.10 \mathrm{~b}$ \\
\hline 40 & $107 \mathrm{~b}$ & $13.0 \mathrm{~b}$ & $0.36 \mathrm{a}$ & $0.15 \mathrm{a}$ \\
\hline 60 & $114 b$ & $5.6 \mathrm{c}$ & $0.33 \mathrm{a}$ & $0.04 \mathrm{c}$ \\
\hline \multicolumn{5}{|l|}{ ANOVA } \\
\hline $\mathrm{P}$ & $* * *$ & $* *$ & NS & NS \\
\hline C & $* * *$ & $* * *$ & $* *$ & $*$ \\
\hline $\mathrm{P} \times \mathrm{C}$ & $* *$ & $* *$ & NS & * \\
\hline $\mathrm{D}$ & $* * *$ & $* * *$ & $* * *$ & $* * *$ \\
\hline$P \times D$ & $* * *$ & $* * *$ & NS & NS \\
\hline $\mathrm{C} \times \mathrm{D}$ & $* * *$ & $* * *$ & NS & $*$ \\
\hline $\mathrm{P} \times \mathrm{C} \times \mathrm{D}$ & $* *$ & $* * *$ & NS & $* *$ \\
\hline
\end{tabular}

$*, * *, * * *$ show significant differences at $p<0.05,0.01$, and 0.001 , respectively. NS, not significant at $p<0.05$. Means in columns followed by different letters are significantly different at $p<0.05$.

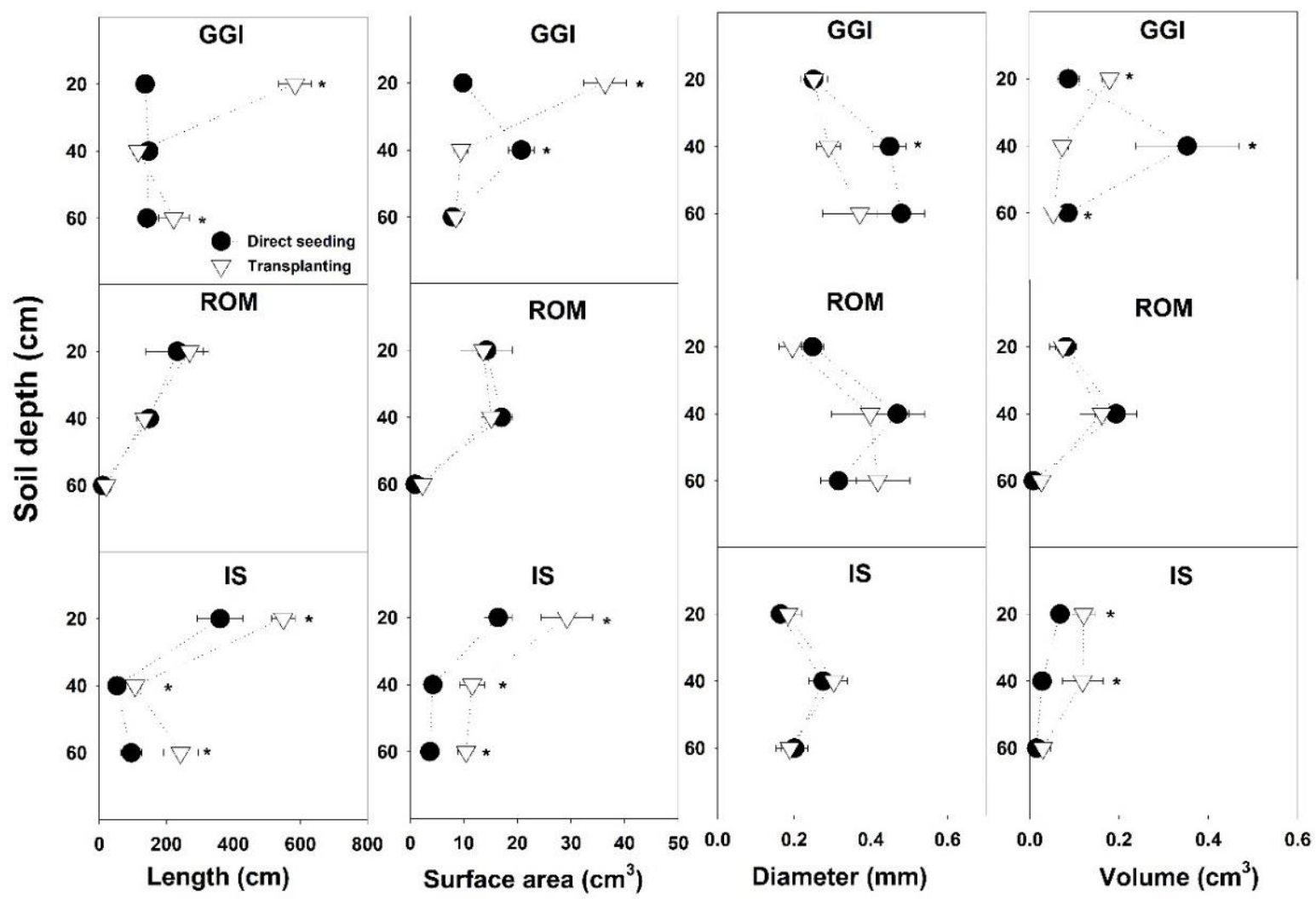

Figure 3. Root components of artichoke cultivars (Green Globe Improved (GGI), Romolo (ROM) or Imperial Star (IS)) as influenced by planting method (direct seeding and transplanting) at three soil depths during the harvesting period, July 2015. Asterisk $\left(^{*}\right)$ within each soil depth represents significant differences between treatments at $p<0.05$. 
Parameters used as a measure of plant morphology (width and height) and their main physiological processes (leaf area index (LAI), chlorophyll content index (SPAD), photosynthesis $(P n)$, stomatal conductance $(g s)$, and transpiration $(E))$ were determined at the vegetative and harvesting stages in both growing seasons. In 2015, plant width, height, and LAI at the harvesting stage as well as SPAD at the vegetative stage were higher in transplanted vs. directly seeded artichokes (Table 3). In 2016, plant size at the vegetation stage was larger for transplanting than the direct seeding method. However, cultivar responses were not significant or inconsistent across the study period. In addition, $P n, g s$, and $E$ for direct seeding and transplanting were statistically similar in both years $(2015,2016)$ and across cultivars (data not presented). Photosynthesis values ranged from $19-21 \mu \mathrm{mol} \mathrm{m}{ }^{-2} \mathrm{~s}^{-1}$ in 2015 and from $28-30 \mu \mathrm{mol} \mathrm{m}^{-2} \mathrm{~s}^{-1}$ in 2016 (numerically higher in 2016); $g \mathrm{~s}$ was about $0.4 \mathrm{~mol} \mathrm{~m}^{-2} \mathrm{~s}^{-1}$ in 2015 and $0.5 \mathrm{~mol} \mathrm{~m}^{-2} \mathrm{~s}^{-1}$ in 2016; $E$ was about $2.5 \mathrm{mmol} \mathrm{m}^{-2} \mathrm{~s}^{-1}$ in 2015 and $5.5 \mathrm{mmol} \mathrm{m}^{-2} \mathrm{~s}^{-1}$ in 2016 . However, gas exchange $(P n, g \mathrm{~s}$, and $E$ ) values for 2015 were about $50 \%$ lower than 2016 across cultivars and over planting methods (direct seeding and transplanting) though the differences between years (2015 vs. 2016) were not statistically analyzed.

Table 3. Plant width and height, leaf area index (LAI), and chlorophyll content index (SPAD) of artichoke cultivars (Green Globe Improved (GGI), Romolo (ROM), and Imperial Star (IS)) as influenced by planting method (direct seeding-Seed, and transplanting-Transplant) during 2015 and 2016 seasons.

\begin{tabular}{|c|c|c|c|c|c|c|c|c|c|}
\hline \multirow{2}{*}{ Year } & \multirow{2}{*}{ Main Effect } & \multicolumn{2}{|c|}{ Width (cm) } & \multicolumn{2}{|c|}{ Height (cm) } & \multicolumn{2}{|c|}{ Leaf Area Index } & \multicolumn{2}{|c|}{ SPAD } \\
\hline & & Vegetative & Harvesting & Vegetative & Harvesting & Vegetative & Harvesting & Vegetative & Harvesting \\
\hline \multirow[t]{9}{*}{2015} & $\begin{array}{l}\text { Planting } \\
\text { method (P) }\end{array}$ & & & & & & & & \\
\hline & Seed & $80.3 \mathrm{~b}$ & $162 \mathrm{~b}$ & $12.0 \mathrm{a}$ & $71.9 \mathrm{~b}$ & $1.60 \mathrm{~b}$ & $3.33 \mathrm{~b}$ & $38.4 \mathrm{~b}$ & $57.0 \mathrm{a}$ \\
\hline & $\begin{array}{l}\text { Transplant } \\
\text { Cultivar (C) }\end{array}$ & $105 \mathrm{a}$ & $191 \mathrm{a}$ & $15.3 \mathrm{a}$ & $93.1 \mathrm{a}$ & $2.10 \mathrm{a}$ & $3.80 \mathrm{a}$ & $44.0 \mathrm{a}$ & $58.7 \mathrm{a}$ \\
\hline & GGI & $88.5 \mathrm{~b}$ & $180 \mathrm{a}$ & $15.2 \mathrm{a}$ & $86.4 \mathrm{a}$ & $1.77 \mathrm{a}$ & $3.19 \mathrm{~b}$ & $42.3 \mathrm{a}$ & $61.0 \mathrm{a}$ \\
\hline & ROM & $97.2 \mathrm{a}$ & $178 \mathrm{a}$ & $14.6 \mathrm{a}$ & $82.5 \mathrm{a}$ & $1.94 \mathrm{a}$ & $3.73 \mathrm{a}$ & $39.8 \mathrm{a}$ & $56.2 \mathrm{a}$ \\
\hline & $\begin{array}{c}\text { IS } \\
\text { ANOVA }\end{array}$ & $92.1 \mathrm{ab}$ & $172 \mathrm{a}$ & $11.0 \mathrm{a}$ & $78.6 \mathrm{a}$ & $1.84 \mathrm{a}$ & $3.77 \mathrm{a}$ & $41.5 \mathrm{a}$ & $56.5 \mathrm{a}$ \\
\hline & $\mathrm{P}$ & * & $* *$ & NS & $* *$ & $*$ & * & $* *$ & NS \\
\hline & C & $*$ & NS & NS & NS & NS & $*$ & NS & NS \\
\hline & $\mathrm{P} \times \mathrm{C}$ & NS & NS & NS & NS & NS & NS & NS & NS \\
\hline \multirow[t]{9}{*}{2016} & $\begin{array}{l}\text { Planting } \\
\text { method }\end{array}$ & & & & & & & & \\
\hline & Seed & $67.2 \mathrm{~b}$ & $160 \mathrm{a}$ & $18.3 \mathrm{~b}$ & $73.5 \mathrm{a}$ & $1.4 \mathrm{a}$ & $5.25 \mathrm{~b}$ & $56.7 \mathrm{a}$ & $60.0 \mathrm{a}$ \\
\hline & $\begin{array}{l}\text { Transplant } \\
\text { Cultivar }\end{array}$ & $89.1 \mathrm{a}$ & $167 \mathrm{a}$ & $21.8 \mathrm{a}$ & $77.8 \mathrm{a}$ & $1.5 \mathrm{a}$ & $5.86 \mathrm{a}$ & $57.2 \mathrm{a}$ & $61.4 \mathrm{a}$ \\
\hline & GGI & $73.3 \mathrm{a}$ & $167 \mathrm{a}$ & $23.8 \mathrm{a}$ & 85.9 a & $1.3 \mathrm{a}$ & $5.10 \mathrm{~b}$ & $59.4 \mathrm{a}$ & $64.5 \mathrm{a}$ \\
\hline & ROM & $90.7 \mathrm{a}$ & $174 \mathrm{a}$ & $20.1 \mathrm{ab}$ & $75.3 \mathrm{ab}$ & $1.6 \mathrm{a}$ & $6.62 \mathrm{a}$ & $56.4 \mathrm{ab}$ & $61.1 \mathrm{ab}$ \\
\hline & $\begin{array}{c}\text { IS } \\
\text { ANVA }\end{array}$ & $70.5 \mathrm{a}$ & $150 \mathrm{~b}$ & $16.3 \mathrm{~b}$ & $65.7 \mathrm{~b}$ & $1.4 \mathrm{a}$ & $4.95 \mathrm{~b}$ & $55.0 \mathrm{~b}$ & $56.6 \mathrm{~b}$ \\
\hline & $\mathrm{P}^{\mathrm{N}}$ & $*$ & NS & $*$ & NS & NS & $* *$ & NS & NS \\
\hline & C & NS & $* * *$ & $* *$ & $*$ & NS & $* *$ & $*$ & $*$ \\
\hline & $\mathrm{P} \times \mathrm{C}$ & NS & NS & NS & NS & NS & NS & NS & NS \\
\hline
\end{tabular}

$*, * *, * *$ show significant differences at $p<0.05,0.01$, and 0.001 , respectively. NS, not significant at $p<0.05$. Means in columns followed by different letters are significantly different at $p<0.05$.

The transplanting method significantly increased artichoke total yield in both 2015 and 2016 growing seasons, when compared to direct seeding (Table 4). In addition, the transplanting method resulted in earlier harvesting and yield in both growing seasons (Figure 4). In 2015, the percentage of heads from early harvests out of the total yield was $58 \%$ for transplanting and $38 \%$ for direct seeding. Similarly, the percentage was $46 \%$ for transplanting and $13 \%$ for direct seeding in 2016. Considering cultivars, IS had the earliest production and the highest yield percentage in the first month, while the ROM cultivar had the latest head production across the study period, 2015-2016 (Figure 4). Specifically, more than $60 \%$ of the total marketable yield for IS occurred between April 6 and 21, 2015 while $65 \%$ of ROM yield occurred between May 5 and May 19 of the same growing season. However, there were no significant differences between treatments (transplant vs. direct seeding) in head quality (chlorogenic acid and cynarin), except for chlorogenic acid in 2016. 
In that year, direct seeding had higher chlorogenic acid concentration in the head than those from the transplanting method (Table 4). In 2015, GGI had higher yield than ROM and IS, while in 2016 GGI and IS had higher yield than ROM (Table 4). Higher yield for GGI was associated with a significantly lower content of chlorogenic acid concentration, especially in 2015 (Table 4). However, there were no significant differences in cynarin concentration between cultivars and across planting methods in both years.

Table 4. Marketable yield, chlorogenic acid, and cynarin of artichoke cultivars (Green Globe Improved (GGI), Romolo (ROM), and Imperial Star (IS)) as influenced by planting method (direct seeding-Seed, and transplanting-Transplant) during 2015 and 2016 seasons.

\begin{tabular}{|c|c|c|c|c|}
\hline Year & Main Effect & $\begin{array}{l}\text { Marketable Yield } \\
\left(\text { ton ha } \mathrm{h}^{-1}\right)\end{array}$ & $\begin{array}{c}\text { Chlorogenic Acid } \\
\left(\mu \mathrm{g} \mathrm{g}^{-1}\right)\end{array}$ & $\begin{array}{l}\text { Cynarin } \\
\left(\mu g^{-1}\right)\end{array}$ \\
\hline \multirow[t]{10}{*}{2015} & Planting method (P) & & & \\
\hline & Seed & $19.9 \mathrm{~b}$ & $125 \mathrm{a}$ & $5.63 \mathrm{a}$ \\
\hline & Transplant & $21.1 \mathrm{a}$ & $138 \mathrm{a}$ & $6.26 \mathrm{a}$ \\
\hline & Cultivar (C) & & & \\
\hline & GGI & $24.3 \mathrm{a}$ & $95 \mathrm{~b}$ & $5.65 \mathrm{a}$ \\
\hline & ROM & $21.9 \mathrm{~b}$ & $140 \mathrm{ab}$ & $6.65 \mathrm{a}$ \\
\hline & IS & $15.2 \mathrm{c}$ & $159 \mathrm{a}$ & $5.53 \mathrm{a}$ \\
\hline & ANOVA & $*$ & & \\
\hline & $\mathrm{P}$ & * & $\underset{*}{N S}$ & NS \\
\hline & $P \times C$ & NS & NS & $\begin{array}{l}\text { NS } \\
\text { NS }\end{array}$ \\
\hline \multirow[t]{10}{*}{2016} & Planting method & & & \\
\hline & Seed & $13.7 \mathrm{~b}$ & $312 \mathrm{a}$ & $6.70 \mathrm{a}$ \\
\hline & Transplant & $18.3 \mathrm{a}$ & $144 \mathrm{~b}$ & $6.23 \mathrm{a}$ \\
\hline & Cultivar & & & \\
\hline & GGI & $17.5 \mathrm{a}$ & $241 \mathrm{ab}$ & $6.76 \mathrm{a}$ \\
\hline & ROM & $15.1 \mathrm{~b}$ & $284 \mathrm{a}$ & $6.21 \mathrm{a}$ \\
\hline & IS & $15.5 \mathrm{ab}$ & $175 \mathrm{~b}$ & $6.52 \mathrm{a}$ \\
\hline & ANOVA & $* * *$ & $* * *$ & NS \\
\hline & C & $*$ & $*$ & $\begin{array}{l}\text { NS } \\
\text { NS }\end{array}$ \\
\hline & $\mathrm{P} \times \mathrm{C}$ & NS & NS & NS \\
\hline
\end{tabular}

$*^{* * *}$ show significant differences at $p<0.05$ and 0.001 , respectively. NS, not significant at $p<0.05$. Means in columns followed by different letters are significantly different at $p<0.05$.

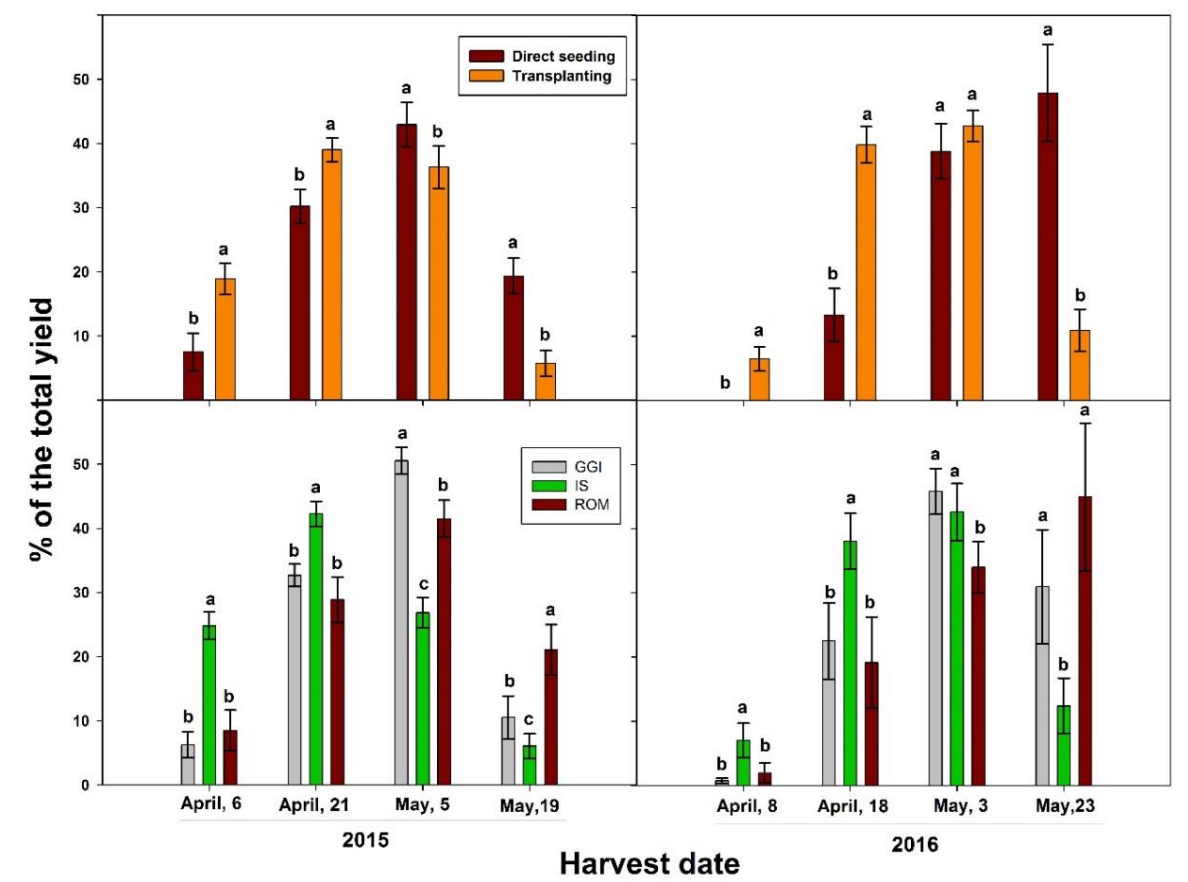

Figure 4. Percentage of the total yield across harvesting periods $(2015,2016)$ of artichoke cultivars (Green Globe Improved (GGI), Romolo (ROM), and Imperial Star (IS)) as influenced by planting methods, direct seeding, and transplanting. Bars within the same harvesting date followed by different letters are significantly different at $p<0.05$. 


\section{Discussion}

\subsection{Root Growth Dynamics}

Comparing both plant establishment systems across the study period data from Tables 1 and 2 showed that transplants had higher mean root $L a$, length, and surface area as compared to direct seeded plants. The expression of root traits is highly associated with plant growth and productivity, as demonstrated in bell pepper and young olive seedlings $[13,15]$. In rice, it has been shown that increases in root components such as root biomass, length, and density, as well as root oxidation activity and root zeatin + zeatin riboside content during the early and mid-growing season, led to higher grain yield [25]. In artichoke seedlings, higher root trait components, such as root length and surface area during the transplanting stage, increased total marketable yield [3,9]. Early research in tomato and pepper has demonstrated that root architecture in direct seeded and transplanted plants are quite different. While direct seeded plants develop a vertical strong taproot in non-compacted soils, transplanted seedlings develop a distinctive root system with typically more basal roots derived from the root-hypocotyl transition zone, which is caused by the early modification of the taproot in the containers; these changes also lead to more uniform growth and higher crop yields compared to direct seeding $[9,15,26,27]$.

Physiologically, the function of diverse root growth components is critical for the establishment of young plants, especially just after planting [25]. At this early stage, the root systems of newly planted seedlings might be inadequate to rapidly supply enough water to shoots, leading to transplant shock $[3,9,28]$. The ability of seedlings to overcome postplanting stress is affected by several factors such as root architecture (size and distribution), root-soil interaction, and root hydraulic conductivity [28]. In this study, most root traits were highly expressed in the topsoil $(0-20 \mathrm{~cm}$ ) (Tables 1 and 2). Artichoke La, root length, and root surface area in the topsoil were greater than the lower soil profiles (Tables 1 and 2). An earlier study in bell pepper by Leskovar et al. [14] found that transplants and direct seeded pepper plants had greater root mass in the 0-10 cm topsoil than in the $10-20 \mathrm{~cm}$ soil depth in a sandy soil (150 and $100 \%$, respectively).

\subsection{Growth, Physiology, Yield, and Head Quality}

Across the study period, the results described in Table 3 show an overall increase in plant size for transplants as compared to direct seeding plants. Rice plants established by transplanting had higher $P n, g \mathrm{~s}$, number of panicles per square meter, seed setting rate, and grain yield, and a smaller number of tillers per plant at the early growth stage and a maximum quantum yield of PSII $\left(F_{v} / F_{m}\right)$ compared to direct seeded plants [29]. Higher shoot width and height as well LAI in transplanted plants can be attributed to a larger root system (root length and surface area, Tables 3 and 4). In lettuce (Lactuca sativa), cultivars with large root systems increased nitrogen use efficiency and displayed higher growth rates, leading to higher yields than those cultivars with smaller roots [30]. Higher mean La in 2016 (compared to 2015) was coupled with higher LAI (shoot canopy) at the harvesting stage. This increase in LAI and La in 2016 could be attributed to higher rainfall received by plants that year as compared to the 2015 growing season. In 2015, the total rainfall and irrigation applied to artichoke plants was $630 \mathrm{~mm}$ (490 rainfall +140 irrigation), while in the 2016 growing season, the total rainfall and applied irrigation was $787 \mathrm{~mm}$ (687 rainfall + 100 irrigation). In addition, higher soil moisture in 2016 led to higher SPAD (vegetation stage) and gas exchange and consequently higher LAI compared to 2015. Interestingly, the transplanting method reduced applied water in a sugar beet (Beta vulgaris) field by about $24 \%$ and evapotranspiration by $25 \%$ as compared with direct seeding [31].

The observed increase in root and shoot growth and higher yield by the transplanting method compared to direct seeding in artichoke confirms previous results in other crops. In rice, transplanted plants had higher yield than direct seeded in both local and high-yielding cultivars [10]. Tomato transplants had higher survival rate, leaf number, and yield, due to more possible harvests than direct seeded plants [32]. Due to the advanced seedling development, transplants exhibit greater fruit sink demand during the 
reproductive development than direct seeded plants [14]. Considering the significant and consistent improvement in root components (La, length, and surface area), shoot size, and early and total marketable yield from transplants across the study period (2015-2016), this establishment method could offer significant benefits to artichoke farmers over direct seeding. In both years, 46 to $50 \%$ of the total yield was harvested in the first month for transplants, while 13 to $38 \%$ in the same period for direct seeded plants (Figure 4). These results agreed with others reported for onion, tomato, and pepper $[5,6,15]$. A comparative response study of direct seeded and transplanted maize (Zea mays) to $\mathrm{N}$ fertilization $(0,120$, 180,240 , and $300 \mathrm{~kg} \mathrm{~N} \mathrm{ha}^{-1}$ ) showed that transplants reached the flowering stage 11 to 15 days earlier and had higher yield than plants established by direct seeding. It is well known that earliness is a trait highly dependent on the cultivar of choice. In our earlier study, that was the case of for IS, an artichoke cultivar classified as early blooming, while the GGI cultivar is considered to be late blooming [33]. In the present study, more than $50 \%$ of the IS yield was harvested in the first month of the harvesting period (2015 and 2016). Interestingly, GGI head production was earlier than ROM (Figure 4) in both years. In fact, $25-45 \%$ of ROM yield was harvested in the last week of the harvesting period, while GGI late yield was about 11\% and 30\% in the latest May harvests of 2015 and 2016, respectively.

Although yield (treatments mean) in 2015 was about $28 \%$ higher than 2016, root and shoot growth was lower compared to 2015, though the differences between years (2015 vs. 2016) were not statistically analyzed. In the 2016 growing season, $P n$ and LAI at harvest were about 40\% higher than in 2015 (Tables 1 and 4). Higher biomass in the 2016 year, when plants received more than $157 \mathrm{~mm}$ of rainfall water than in 2015, might have led to changes in the source-sink relationship, directing more investment of assimilates towards shoot growth to compensate for the larger canopy. We speculate that a higher supply of water in 2015 might have induced the artichoke plants to invest more in forming heads (stronger sinks) than in biomass of the canopy.

Globe artichoke is a valuable crop and a rich source of antioxidants, such as phenolic acids, flavonoids, and cynarin, which have been used for therapeutic effects $[18,19,34,35]$. Plants produce reactive oxygen species (ROS) in stress conditions (e.g., drought) and to detoxify ROS, the antioxidants and flavonoids play a key role in protecting plants from abnormal abiotic stresses $[36,37]$. Significant increases in shoot and reproductive growth have been normally coupled with reductions in nutrient and protein concentrations in tissues due to dilution effects $[21,23,38]$. In this study, this dilution effect was noticed in the content of chlorogenic acid in 2016 (Table 4), where the significant increase (34\%) in artichoke yield from the transplanting method produced heads with reduced (54\%) chlorogenic acid. However, cynarin levels from the transplanting and direct seeding heads were statistically similar.

\section{Materials and Methods}

\subsection{Site Description}

A two-year field study was conducted at the Texas A\&M AgriLife Research and Extension Center at Uvalde, Texas (long. $29^{\circ} 12^{\prime} 57.6^{\prime \prime} \mathrm{N}$, lat. $99^{\circ} 45^{\prime} 21.6^{\prime \prime} \mathrm{W}$ ) from October 2014 to August 2016. The soil was a clay type (hyperthermic Aridic Calciustolls of the Uvalde series) with the following chemical properties: $\mathrm{pH}$ 8.0, EC $0.6 \mathrm{dS} \mathrm{m}^{-1}, \mathrm{P} 55 \mathrm{mg} \mathrm{kg}^{-1}$, $\mathrm{K} 810 \mathrm{mg} \mathrm{kg}^{-1}, \mathrm{Ca}^{+2} 12,939 \mathrm{mg} \mathrm{kg}{ }^{-1}, \mathrm{Mg}^{+2} 333 \mathrm{mg} \mathrm{kg}^{-1}, \mathrm{~S} 29 \mathrm{mg} \mathrm{kg}^{-1}, \mathrm{Na} 50 \mathrm{mg} \mathrm{kg}^{-1}$, and nitrate- $\mathrm{N} 59 \mathrm{mg} \mathrm{kg}^{-1}$. In the 2015 growing season, the mean growing temperature was $23{ }^{\circ} \mathrm{C}$, relative humidity $64 \%$, and total rainfall $490 \mathrm{~mm}$, while in 2016 the mean temperature was $21^{\circ} \mathrm{C}$, relative humidity $67 \%$, and total rainfall $687 \mathrm{~mm}$ (Figure 5). The plant hardiness zone for the Uvalde site location is 8. Average annual extreme minimum temperatures range from -12.2 to -6.7 . 


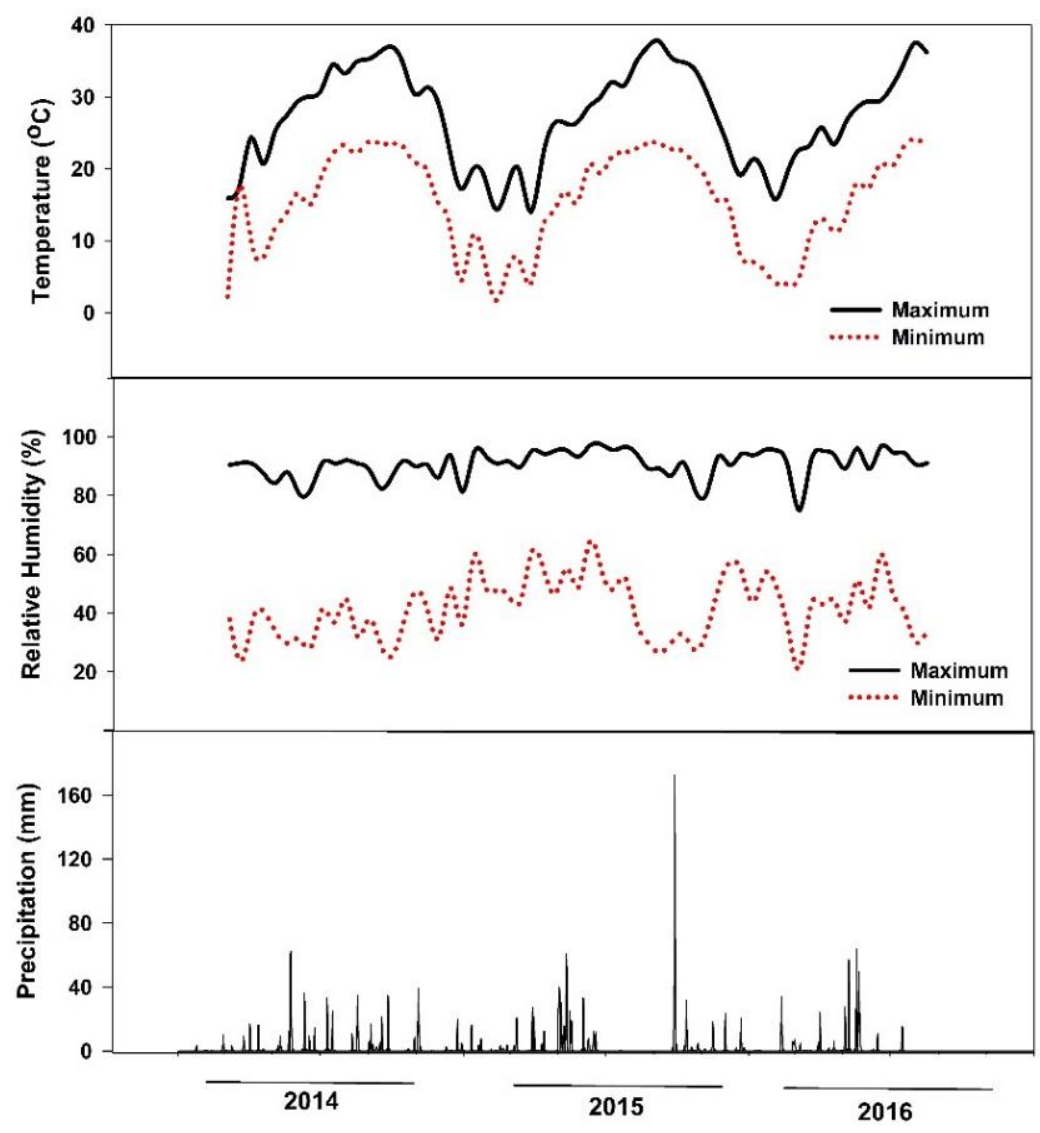

Figure 5. Maximum and minimum air temperature, air relative humidity, and precipitation of the study site at Uvalde, Texas, during the experimental period (October 2014-August 2016).

\subsection{Stand Establishment and Cultivar Treatments}

We evaluated two planting methods, direct seeding and transplanting, on three artichoke cultivars, Green Globe Improved (GGI), Imperial Star (IS), and Romolo (ROM). GGI and IS (Big Heart Seed Co, Brawley, California) are open pollinated cultivar types with green to light purple heads, while ROM is a contemporary hybrid cultivar (Big Heart Seed Co, Brawley, California) with predominantly purple heads.

For the transplanting treatment, artichoke seeds of the three cultivars were sown in polystyrene Speedling trays (one seed per cell) containing 128 cells $(3.2 \times 3.2 \mathrm{~cm}$ square and $6.4 \mathrm{~cm}$ deep) and placed in a germination chamber for 4 days in darkness inside an incubator chamber set at $20{ }^{\circ} \mathrm{C}$. A 3:1 peatmoss:perlite growing medium was used and only initial watering was required during the incubation period. Then, seedlings were transferred to greenhouse conditions (temperature $23 \pm 2{ }^{\circ} \mathrm{C}$, humidity $60 \pm 5 \%$ ) and grown for 7 weeks before field planting. Direct seeding and transplanting were performed simultaneously in the open field on October 28, 2014 (first growing season) and on November 23, 2015 (second growing season). Plants started in 2014 were abandoned after harvest in 2015, and completely new plants were prepared for analysis in 2016. Both establishment and cultivar treatments were planted in separate blocks, each consisting of three beds $1.5 \mathrm{~m}$ apart, using a single row per bed at a spacing of $0.9 \mathrm{~m}$ between plants. Beds were laid out with a black plastic mulch to reduce weed pressure and soil evaporative water losses. The outside rows were used as buffers and the middle row was used for growth measurements and harvests. For the direct seeded treatment, three seeds per hole were seeded in the field and thinned to one plant after six weeks to be comparable with the transplanting method. 


\subsection{Field Management}

In each growing season, N-P-K fertilizers were applied to reach a total rate of $150 \mathrm{~N}$, $100 \mathrm{P}$ and $100 \mathrm{~K} \mathrm{~kg} \mathrm{ha}^{-1}$. Fertilizers (4N-4.4P-8.3K and 32N-0P-0K) were applied in 3 split doses each year. The first dose ( $20 \%$ of total fertilizers) was applied the third week after transplanting, the second dose $(40 \%)$ at the 8 -leaf stage, and the third $(40 \%)$ prior to the beginning of the harvest stage. In both seasons, irrigation was established by a subsurface drip system placed in the middle of the bed at a $15 \mathrm{~cm}$ depth. In the 2015 growing season, the number of irrigations was 10 (total irrigation was $140 \mathrm{~mm}, 10-15 \mathrm{~mm}$ per irrigation) while in 2016 the number of irrigations was 7 (total irrigation was $100 \mathrm{~mm}, 10-15 \mathrm{~mm}$ per irrigation). The total rainfall and irrigation for the 2015 growing season was $630 \mathrm{~mm}$ (490 rainfall +140 irrigation) and $787 \mathrm{~mm}$ (687 rainfall +100 irrigation) for 2016. Overall, the total amount of water received by plants was between 630 and $787 \mathrm{~mm}$ across the study period. Gibberellic acid $\left(\mathrm{GA}_{3}, 4 \%, \mathrm{CP}\right.$ Bio, Inc., Chino, $\left.\mathrm{CA}\right)$ was sprayed twice at $20 \mathrm{mg}$ $\mathrm{L}^{-1}$, the first application at the 4th leaf stage and the second $10 \mathrm{~d}$ thereafter. Esfenvalerate (Asana $\mathrm{XL}, 8.4 \%$ by weight, DuPont, Wilmington, DE, USA) at $70 \mathrm{~mL} \mathrm{ha}^{-1}$ was applied to control cucumber beetle (Diabrotica undecimpunctata) and cut worms during the vegetative stage. During early head development till harvest, calcium (5\%) and zinc (5\%) (Tracite, Helena Chemical Co., Fresno, CA, USA) were applied weekly to prevent head atrophia, a physiological disorder typically associated with calcium deficiency [3].

\subsection{Root Measurements}

Root measurements were conducted four times during each growing season following the procedures of Othman and Leskovar [13] and Sharma et al. [39]. Root measurements were taken using the minirhizotron technique with acrylic tubes of $182 \mathrm{~cm}$ in length and $50.8 \mathrm{~mm}$ in diameter. Minirhizotron tubes were installed $30 \mathrm{~cm}$ away from the seedlings at a $45^{\circ}$ angle from the vertical using a trailer-mounted Giddings hydraulic probe (5-TS MODEL-MGSRTS, Giddings Machine Co., Windsor, CO, USA). The aboveground $30 \mathrm{~cm}$ of the minirhizotron tubes were painted with a double layer of black (inside) and white (outside) paint to prevent light penetration and the top end of each tube was covered with a PVC end cap for further light and moisture protection. In both growing seasons, five specific soil depth (SSD) ranges were used, $0-20,20-40,40-60,60-80$, and $80-100 \mathrm{~cm}$. The SSD of each photo was calculated following the procedure of Rasmussen and ThorupKristensen [40] as $\cos \left(45^{\circ}\right) \times$ tube depth of the photo. As the minirhizotron tubes were installed at a $45^{\circ}$ angle from the vertical line, four minirhizotron images were collected within each interval depth and the four values from each soil depth interval were averaged to one value prior to statistical analysis. A microscope camera system (Bartz Technology Corporation, Carpinteria, CA, USA) was used to capture the root pictures from the upper interface of the tube and the soil $[39,40]$. The total area represented in each image was $3.24 \mathrm{~cm}^{2}$. Images were analyzed using WinRHIZOTron software (Régent Instruments Inc., Quebec, QC, Canada) and presented as $\mathrm{La}\left(\mathrm{mm} \mathrm{cm}^{-2}\right.$; total root length per image area $\left.\left(3.24 \mathrm{~cm}^{2}\right)\right)$.

Different soil horizons (0-20, 20-40, and 40-60 cm soil depth) were also collected during the harvesting stage in June 2015. Root samples from both treatments and across cultivars were carefully washed under a set of large to fine screens, roots were separated, and then root components were measured using a WinRHIZO image analysis system (V5.0, Regent Instruments, Quebec, QC, Canada).

\subsection{Shoot Morphology, Leaf Physiology, and Yield}

Parameters used as a measure of plant morphology (width and height) and their main physiological processes (LAI, SPAD, $P n, g \mathrm{~s}$, and $E$ ) were determined during vegetative and harvesting stages in both growing seasons. Gas exchange $(P n, g \mathrm{~s}$, and $E)$ was measured using a portable photosynthesis system (LI-6400XT; LI-COR, Lincoln, NE, USA) following the procedures of Othman et al. [41]. Leaf-level gas exchange measurements were carried out between 11:00 a.m. and 1:00 p.m. on sun-exposed and fully matured leaves (2 leaves 
per replicate, two measurement per growing season) $[42,43]$. Light intensity was set to track ambient photosynthetically active radiation, area of chamber head to $6 \mathrm{~cm}^{2}$, flow rate to $500 \mu \mathrm{mol} \mathrm{s}{ }^{-1}$, temperature in the cuvette to ambient air and reference $\mathrm{CO}_{2}$ to $390 \mu \mathrm{mol}$. SPAD was measured using a chlorophyll meter (SPAD-502 Plus, Minolta, Japan), and LAI was measured using a ceptometer (LP-80, Decagon Devices, Pullman, WA, USA). Artichoke harvests were conducted between April and May 2015 and 2016 and marketable yield $\left(\mathrm{t} \mathrm{ha}^{-1}\right)$ was determined. A head was considered marketable when its diameter was larger than $7 \mathrm{~cm}$, without tipburn and/or open bracts [20]. In both growing seasons (2015 and 2016), a representative sample of eight heads per treatment was taken and used to measure phytochemical (chlorogenic acid and cynarin) concentration using a high-performance liquid chromatography system (HPLC, Waters Alliance 2695 Separation Module, Milford, MA 01757, USA).

\subsection{Statistical Analysis}

The study was designed using a randomized complete block design with four replications and two factors (two planting methods, three cultivars). The analysis of variance (ANOVA) and the least significant difference test $(p<0.05)$ in SAS (Version 9.4 for Windows; SAS Institute, Cary, NC, USA) were used to identify differences between planting methods (direct seeding vs. transplanting), cultivars, and their interactions.

\section{Conclusions}

Overall, the two-year field assessment of stand establishment methods, transplanting and direct seeding, revealed significant quantitative responses of root trait components, which were translated into yield differences between the two systems in the three cultivars evaluated. Transplants consistently exhibited increased $\mathrm{La}$, root length, and surface area, as well as shoot size, chlorophyll content index, and marketable yield. However, no significant differences were found in root diameter and volume, leaf-level gas exchange $(P n, g s$, and $E)$, and head cynarin concentration across the study period. Given that higher yield is the main concern for artichoke growers, this study supports that transplanting is the best growing method for globe artichoke cultivars. Since globe artichoke has one of the highest total antioxidant capacities among all vegetables, our future research will focus on how to couple the increase in artichoke yield with optimal concentrations of antioxidant compounds and enzymes in the heads. That research will provide a better understanding on the balance between yield promotion and phytonutrient quality, including the level of protection from oxidative stress in transplanted globe artichoke plants.

Author Contributions: Conceptualization, D.I.L.; methodology, D.I.L. and Y.A.O.; software, Y.A.O.; formal analysis, D.I.L. and Y.A.O.; investigation, D.I.L. and Y.A.O.; data curation, D.I.L. and Y.A.O.; writing-original draft preparation, D.I.L. and Y.A.O.; writing-review and editing, D.I.L.; supervision, D.I.L.; project administration, D.I.L. All authors have read and agreed to the published version of the manuscript.

Funding: This research was partially funded by the Texas Department of Agriculture, Specialty Crop Block Grant Program under grant number SCFB-1314-14.

Institutional Review Board Statement: Not applicable.

Informed Consent Statement: Not applicable.

Acknowledgments: The material is based upon work that is supported by the National Institute of Food and Agriculture, United States Department of Agriculture, Multi-state Project W-4168. We thank our staff Manuel Figueroa-Pagan, Juan Esquivel, Carrie Hensarling, Madhumita Joshi, and Audra Elrod for their assistance in the laboratory and field. Appreciation is also extended to Rusty Jordan from Big Heart Seed Co. (Brawley, CA, USA) for providing the new globe artichoke hybrid seeds.

Conflicts of Interest: The authors declare no conflict of interest. 


\section{References}

1. Dale, A.; Drennan, S. Transplanted maize (Zea mays) for grain production in Southern England. I. Effects of planting date, transplant age at transplanting and cultivar on grain yield. J. Agric. Sci. 1997, 128, 27-35. [CrossRef]

2. Fanadzo, M.; Chiduza, C.; Mnkeni, P. Comparative response of direct seeded and transplanted maize (Zea mays L.) to nitrogen fertilization at Zanyokwe irrigation scheme, Eastern Cape, South Africa. Afr. J. Agric. Res. 2009, 4, 689-694.

3. Leskovar, D.; Othman, Y. Low nitrogen and fertigation practices can improve artichoke transplant quality and yield. HortScience 2016, 51, 567-572. [CrossRef]

4. Leskovar, D.; Othman, Y. Nitrogen management for improving root and shoot components of young 'Arbequina' olives. HortScience 2019, 54, 175-180. [CrossRef]

5. Leskovar, D.; Cantliffe, D. Transplant production systems influence growth and yield of fresh-market tomatoes. J. Am. Soc. Hort. Sci. 1994, 119, 662-668. [CrossRef]

6. Ketema, S.; Dessalegn, L.; Tesfaye, B. Effect of planting methods on maturity and yield of onion (Allium cepa var. cepa) in the central rift valley of Ethiopia. Ethiop. J. Agric. Sci. 2013, 24, 45-55.

7. Palma, A.; Laurance, S. A review of the use of direct seeding and seedling plantings in restoration: What do we know and where should we go? Appl. Veg. Sci. 2015, 18, 561-568. [CrossRef]

8. Douglas, G.; Dodd, M.; Power, I. Potential of direct seeding for establishing native plants into pastoral land in New Zealand. N. Z. J. Ecol. 2007, 31, 143-153.

9. Leskovar, D.; Othman, Y. Pre-transplant conditioning to mitigate heat, drought and biotic stresses in artichoke. Acta Hortic. 2016, 1147, 145-154. [CrossRef]

10. Hossain, M.; Salam, M.; Uddin, M.; Pervez, Z.; Sarkar, M. A comparative study of direct seeding versus transplanting method on the yield of Aus rice. Pak. J. Agron. 2002, 1, 86-88. [CrossRef]

11. Macias-Leon, M.; Leskovar, D. Containerized onion transplants: A management system to enhance growth, yield, and quality. HortScience 2019, 54, 60-69. [CrossRef]

12. Hongyan, L.; Weiqin, W.; Aibin, H.; Lixiao, N. Correlation of leaf and root senescence during ripening in dry seeded and transplanted rice. Rice Sci. 2018, 25, 279-285. [CrossRef]

13. Othman, Y.; Leskovar, D. Nitrogen management influenced root length intensity of young olive trees. Sci. Hortic. 2019, 246, 726-733. [CrossRef]

14. Leskovar, D.; Cantliffe, D.; Stoffella, P. x Root growth and root-shoot interaction in transplants and direct seeded pepper plants. Environ. Exp. Bot. 2019, 30, 349-354. [CrossRef]

15. Leskovar, D.; Cantliffe, D. Comparison of plant establishment method, transplant, or direct seeding on growth and yield of bell pepper. J. Am. Soc. Hort. Sci. 1993, 118, 17-22. [CrossRef]

16. Vemmos, S.; Petri, E.; Stournaras, V. Seasonal changes in photosynthetic activity and carbohydrate content in leaves and fruit of three fig cultivars (Ficus carica L.). Sci. Hort. 2013, 160, 198-207. [CrossRef]

17. Bhusal, N.; Bhusal, S.; Yoon, T. Comparisons of physiological and anatomical characteristics between two cultivars in bi-leader apple trees (Malus $\times$ domestica Borkh.). Sci. Hort. 2018, 231, 73-81. [CrossRef]

18. Ciancolini, A.; Alignan, M.; Pagnotta, M.; Miquel, J.; Vilarem, G.; Crinò, P. Morphological characterization, biomass and pharmaceutical compounds in Italian globe artichoke genotypes. Ind. Crop. Prod. 2013, 49, 326-333. [CrossRef]

19. Moglia, A.; Lanteri, S.; Comino, C.; Acquadro, A.; Beekwilder, J. Stress-induced biosynthesis of dicaffeoylquinic acids in globe artichoke. J. Agric. Food Chem. 2008, 56, 8641-8649. [CrossRef]

20. Leskovar, D.; Othman, Y. Organic and conventional farming differentially influenced soil respiration, physiology, growth and head quality of artichoke cultivars. J. Soil Sci. Plant Nutr. 2018, 18, 865-880. [CrossRef]

21. Othman, Y.; Leskovar, D. Organic soil amendments influence soil health, yield, and phytochemicals of globe artichoke heads. Biol. Agric. Hortic. 2018, 34, 258-267. [CrossRef]

22. Othman, Y.; Leskovar, D. Farming system and sources of organic matter: Influence on soil health, yield, and head quality of globe artichoke. Acta Hortic. 2020, 1284, 93-100. [CrossRef]

23. Sharaf-Eldin, M.; Schnitzler, W.; Nitz, G.; Razin, A.; El-Oksh, I. The effect of gibberellic acid (GA3) on some phenolic substances in globe artichoke (Cynara cardunculus var. scolymus (L.) Fiori). Sci. Hortic. 2007, 111, 326-329. [CrossRef]

24. Shinohara, T.; Agehara, S.; Yoo, K.; Leskovar, D. Irrigation and nitrogen management of artichoke: Yield, head quality, and phenolic content. HortScience 2011, 46, 377-386. [CrossRef]

25. Zhang, H.; Xue, Y.; Wang, Z.; Yang, J.; Zhang, J. Morphological and physiological traits of roots and their relationships with shoot growth in "super" rice. Field Crop. Res. 2009, 113, 31-40. [CrossRef]

26. Leskovar, D.; Clark, J.; Sprague, R. Yield, quality, and water use efficiency of muskmelon are affected by irrigation and transplanting versus direct seeding. HortScience 2001, 36, 286-291. [CrossRef]

27. McKee, J. Physiological aspects of transplanting vegetables and other crops. I. Factors which influence re-establishment. Hort. Abstr. 1981, 51, 265-272.

28. Grossnickle, C. Importance of root growth in overcoming planting stress. New For. 2005, 30, 273-294. [CrossRef]

29. Song, C.; Sheng-guan, C.; Xin, C.; Guo-ping, Z. Genotypic differences in growth and physiological responses to transplanting and direct seeding cultivation in rice. Rice Sci. 2009, 16, 143-150. [CrossRef] 
30. Kerbiriou, P.; Stomph, T.; Bueren, E.; Struik, P. Influence of transplant size on the above- and below-ground performance of four contrasting field-grown lettuce cultivars. Front. Plant Sci. 2013, 4, 379. [CrossRef] [PubMed]

31. Khozaei, M.; Haghighi, A.; Parsa, S.; Sepaskhah, A.; Razzaghi, F.; Yousefabadi, V.; Emam, Y. Evaluation of direct seeding and transplanting in sugar beet for water productivity, yield and quality under different irrigation regimes and planting densities. Agric. Water Manag. 2020, 238, 106230. [CrossRef]

32. Javanmardi, J.; Moradiani, M. Tomato transplant production method affects plant development and field performance. Int. J. Veg. Sci. 2017, 23, 31-41. [CrossRef]

33. Leskovar, D.; Othman, Y. Morpho-physiological characteristics and yield of early and Mid-season globe artichoke. Acta Hortic. 2016, 1147, 155-158. [CrossRef]

34. Gezer, C.; Yucecan, S.; Rattan, S. Artichoke compound cynarin differentially affects the survival, growth, and stress response of normal, immortalized, and cancerous human cells. Turk. J. Biol. 2015, 39, 299-305. [CrossRef]

35. Lattanzio, V.; Kroon, P.; Linsalata, V.; Cardinali, A. Globe artichoke: A functional food and source of nutraceutical ingredients. J. Funct. Foods 2009, 1, 131-144. [CrossRef]

36. Bhusal, N.; Lee, M.; Lee, H.; Adhikari, A.; Han, A. Evaluation of morphological, physiological, and biochemical traits for assessing drought resistance in eleven tree species. Sci. Total Environ. 2021, 779, 146466. [CrossRef]

37. Khaleghi, A.; Naderi, R.; Brunetti, C.; Maserti, B.; Salami, S.; Babalar, M. Morphological, physiochemical and antioxidant responses of Maclura pomifera to drought stress. Sci. Rep. 2019, 9, 19250. [CrossRef]

38. Jarrell, W.; Beverly, R. The dilution effect in plant nutrition studies. In Advances in Agronomy; Academic Press: New York, NY, USA, 1981; pp. 197-224. [CrossRef]

39. Sharma, S.; Leskovar, D.; Crosby, K.; Volder, A. Root growth dynamics and fruit yield of melon (Cucumis melo L.) genotypes at two locations with sandy loam and clay soils. Soil Tillage Res. 2017, 168, 50-62. [CrossRef]

40. Rasmussen, I.; Thorup-Kristensen, K. Does earlier sowing of winter wheat improve root growth and Nuptake? Field Crop. Res. 2016, 196, 10-21. [CrossRef]

41. Othman, Y.; Van Leeuwen, D.; Heerema, R.; St. Hilaire, R. Midday stem water potential values needed to maintain photosynthesis and gas exchange established for pecans. J. Amer. Soc. Hort. Sci. 2014, 139, 537-546. [CrossRef]

42. Tadros, M.; Al-Mefleh, N.; Othman, Y.; Al-Assaf, A. Water harvesting techniques for improving soil water content, and morphophysiology of pistachio trees under rainfed conditions. Agric. Water Manag. 2021, 243, 106464. [CrossRef]

43. A'saf, T.; Al-Ajlouni, M.; Ayad, J.; Othman, Y.; St. Hilaire, R. Performance of six different soilless green roof substrates for the Mediterranean region. Sci. Total Environ. 2020, 730, 139182. [CrossRef] [PubMed] 